\title{
QUAIS SENTIDOS PARA GÊNERO? UMA ANÁLISE DE DICIONÁRIOS
}

\author{
WHICH MEANINGS \\ ARE THERE FOR GENDER? \\ ¿CUÁLES SIGNIFICADOS \\ PARA GÉNERO? \\ AN ANALYSIS OF DICTIONARIES \\ UN ANÁLISIS DE DICCIONÁRIOS
}

\section{Laís Virginia Alves Medeiros*}

Universidade Estadual de Campinas, Instituto de Estudos da Linguagem, Campinas, SP, Brasil

\begin{abstract}
Resumo: Este artigo, situado no campo da História das Ideias Linguísticas, analisa diferentes definições para a entrada gênero em dois dicionários de língua e dois dicionários especializados. O objetivo é investigar como a diferença sexual e a identidade de gênero são elaboradas (ou silenciadas) em diferentes instrumentos linguísticos. Partindo do campo da História das Ideias Linguísticas a partir de Collinot e Mazière (1997) e autores brasileiros (OLIVEIRA, 2006; NUNES, 1996), reflete sobre instrumentos linguísticos e gramatização. Em seguida, apresenta os critérios para a construção do corpus e procede à análise dos verbetes. Os resultados apontam uma regularidade que permeia gênero nos dicionários de língua e nos dicionários especializados: as relações com categorias e diferenças. As especificidades que delineiam diferentes sentidos dependem do funcionamento de gênero nos campos do saber que são incluídos ou deixados de fora em cada definição.
\end{abstract}

Palavras-chave: Gênero. História das Ideias Linguísticas. Discurso. Dicionário de língua. Dicionário especializado.

Abstract: Situated in the field of History of Linguistics Ideas, this paper offers an analysis in the field of History of Linguist Ideas of different definitions for the entry word gender in two language dictionaries and two specialized dictionaries. Our objective is to investigate how the exploration and silencing of sexual differentiation and gender identity act in different linguistic instruments. Based on the theoretical framework of the History of Linguistic Ideas developed by Collinot and Mazière (1997), as well as on Brazilian references (OLIVEIRA, 2006; NUNES, 1996), we reflect upon linguistic instruments and gramatization. Subsequently, we present the criteria for the construction of our corpus and proceed to the entries' analysis. The results point to a regularity that permeates the definitions of gender in both the language and the specialized dictionaries: its relations with categories and differences. The specificities that outline distinct meanings depend on the way the word gender functions in the knowledge fields that are included or excluded in each definition.

Keywords: Gender. History of Linguistic Ideas. Discourse. Language dictionary. Specialized dictionary.

Resumen: Este artículo se sitúa en el campo de la Historia de las Ideas Lingüísticas, analiza diferentes definiciones para la entrada género en dos diccionarios de lengua y dos diccionarios especializados. El objetivo es investigar cómo la diferencia sexual y la identidad de género son elaboradas (o silenciadas) en diferentes instrumentos lingüísticos. Partiendo del campo de la Historia de las Ideas Lingüísticas desde

\footnotetext{
* Doutoranda em Linguística na Universidade Estadual de Campinas (Unicamp) com bolsa do Conselho Nacional de Desenvolvimento Científico e Tecnológico (CNPq). Integrante dos grupos de pesquisa Mulheres em Discurso e ALHURes - Análise do Discurso, Linguagem, História, Urbano e Resistência. ORCID: https://orcid.org/0000-0003-3467-8066. E-mail: lais.v.medeiros@gmail.com.
} 
Collinot y Mazière (1997) y autores brasileños (OLIVEIRA, 2006; NUNES, 1996), reflexiona sobre instrumentos lingüísticos y de gramática. A continuación, presenta criterios para construcción del corpus y hace el análisis de las entradas. Los resultados apuntan regularidad que impregna género en los diccionarios de lengua y en los diccionarios especializados: las relaciones con categorías y diferencias. Las especificidades que delinean diferentes sentidos dependen del funcionamiento de género en los campos del saber que son incluidos o dejados fuera en cada definición.

Palabras clave: Género. Historia de las Ideas Lingüísticas. Discurso. Diccionario de lengua. Diccionario especializado.

\section{INTRODUÇÃO}

A equivocidade da língua e a impossibilidade de uma relação transparente entre palavra e sentido já é consenso em algumas áreas da Linguística. O cotejamento e a análise de diferentes instrumentos linguísticos permitem uma compreensão não apenas dessa equivocidade, mas do próprio funcionamento da língua em sua instrumentalização: as tecnologias linguísticas, conforme Orlandi e Guimarães (2001), não são apenas produto de um saber, mas contribuem para a constituição dos fatos da língua.

Nos estudos do discurso que centram suas análises sobre o discurso feminista, os estudos de gênero em intersecção com o movimento feminista estão na base do referencial teórico. No entanto, este não é o único, tampouco o mais familiar, sentido de gênero que circula na sociedade. Qual relação entre discursos sobre gênero é identificável no discurso do dicionário? Como pode ser estabelecida nas definições dos dicionários a relação entre a noção de gênero e a palavra gênero? É uma palavra que remonta à língua comum ou à língua especializada?

Não ignoramos o potencial político e polêmico da palavra, principalmente num momento histórico em que ganham espaço no Brasil debates inflamados sobre "ideologia de gênero". Se entendemos que língua e ideologia não se separam, as definições de gênero em diferentes dicionários podem servir como observatório para o modo como diferentes saberes são reforçados (ou silenciados), atendendo a diferentes propósitos conforme as condições de produção em que esses instrumentos linguísticos são produzidos e como circulam. A subjetividade, os processos de identificação de gênero e a diferença sexual são sentidos pertinentes para constarem, por exemplo, num dicionário escolar? Como esses aspectos são (se são) definidos nos dicionários de língua e nos dicionários especializados?

Tendo essas perguntas como questões norteadoras, este artigo começa por uma reflexão situada no campo da História das Ideias Linguísticas (doravante HIL) sobre o funcionamento do dicionário como discurso. Em seguida, passamos à explicação do processo de construção do corpus, apresentando os dicionários selecionados e os critérios para seleção, para em seguida proceder à análise dos verbetes selecionados. A essa análise, seguem a discussão dos resultados e as considerações finais. 
Ao propor a análise do instrumento linguístico dicionário na intersecção entre análise do discurso e lexicografia, Collinot e Mazière (1997, p. 50) apontam que esse instrumento é criado em dependência com três aspectos principais. Um deles é "o discurso dominante e/ou contraditório de uma época". Tomando como exemplo o século XIX, os autores destacam que a lexicografia, no que se refere às mudanças de sentido, teve influência do frenesi da história. Um segundo aspecto é a filosofia da época: ainda tomando o século XIX como exemplo, os autores comparam como à época era o positivismo que modelava a descrição do sentido, enquanto contemporaneamente são a história e a sintaxe que organizam essa descrição. Finalmente, o terceiro aspecto é que o dicionário representa um engajamento militante, relacionado à ideia que se tem de língua, e também um engajamento social. É mantendo em vista essas três dependências que é possível considerar o dicionário "uma construção historicizada pela própria natureza de seu objeto, a palavra" (COLLINOT; MAZIÈRE, 1997, p. 51). A partir dessa tríade, questionamos: quais aspectos vêm à tona no que se refere à nossa época, à nossa língua $\mathrm{e}$ à nossa sociedade quando analisamos as definições de gênero em diferentes instrumentos linguísticos?

A partir da análise do dicionário Grand Robert de la langue française, os autores descrevem o papel do lexicógrafo de um modo que pode se assemelhar à produção dos demais instrumentos linguísticos: o lexicógrafo está imerso nas redes de discurso que tenta conectar, ocupando uma dupla posição de observador e de ator das práticas linguageiras, o que obriga a reconhecer um tanto de empirismo nesse processo. Além disso, o modo de organização dos dicionários também sofre influência daquilo que os autores chamam de "modalidades discursivas de representações do público" (COLLINOT; MAZIÈRE, 1997, p. 72). Isso quer dizer que o dicionário é construído para um público suposto, projetado, que teria um dado conhecimento sobre a língua e recorreria ao dicionário com um certo objetivo. Essa representação pode ser fundamental para entender, na análise de um determinado verbete, como sua definição pode corresponder a um dado imaginário de leitor e mesmo de língua.

É nesse sentido que os autores interpretam a nomenclatura apresentada nos dicionários como "um discurso cujo objeto seria uma teoria implícita da palavra" (COLLINOT; MAZIÈRE, 1997, p. 82). Essa teoria diz respeito ao duplo status da palavra, que a coloca na intersecção de dois modos organizacionais da atividade linguageira: ora ela é tomada na ordem da língua, ora é tomada na ordem do discurso. É pelas entradas dos verbetes nos dicionários que esse duplo funcionamento é explicado. Para os autores, uma mesma palavra, quando colocada em destaque como verbete, é tomada como uma unidade semiótica que pertence ao sistema da língua. Já quando é colocada na descrição do verbete (seja integrando a definição, seja integrando um exemplo de uso), passa a ser considerada segundo relações distribucionais, como um segmento de discurso. É desse modo que a palavra estabelece, na interseção entre as duas ordens, uma relação entre as regularidades da língua e as regularidades que se atualizam 
em diferentes formações discursivas ${ }^{1}$. Isso importa porque, ao cotejar diferentes dicionários de língua, as regularidades identificadas podem não encontrar correspondência entre aquilo que a estabilização da língua apresenta e aquilo que é mobilizado em certas formações discursivas (ponto crucial na análise de palavras que aparecem frequentemente em discursos de militância).

$\mathrm{Na}$ leitura dos autores, a formação dos enunciados lexicográficos é regida por um discurso, de modo que:

a palavra enquanto forma discursiva pertencente ao discurso do dicionário é um fenômeno observável a partir de uma base linguística, ou seja, uma teoria dos termos lexicais, que deve conduzir não a uma teoria da sintaxe - o que voltaria a considerar o termo lexical como "átomo sintático" - mas a uma interpretação historicizada das formas de significação, e então colocar o termo lexical como palavra segmento de discurso (COLLINOT; MAZIÈRE, 1997, p. 101).

Além disso, os autores destacam que o dicionário é uma instituição linguística, pois ensina um saber sobre uma língua. Quando da análise da disposição desse saber, tomando a palavra pelo ponto de vista discursivo, há de se atentar para que não ocorram duas atitudes criticáveis. A primeira diz respeito à "tentação do sociologismo baseada na ilusão de uma coincidência entre posição social e posição de discurso" (COLLINOT; MAZIÈRE, 1997, p. 121), ou seja, à possibilidade de considerar que, linguisticamente falando, existam diferentes línguas para diferentes classes ${ }^{2}$. A segunda é a "tentação de uma origem secreta do sentido reformulável em não dito ou já dito" (COLLINOT; MAZIÈRE, 1997, p. 121), cujo lugar deve ser ocupado por uma ênfase na irrupção do acontecimento e nas regras que permitiram que um dado enunciado (e não outro) fosse construído da maneira como foi. Essas críticas guiarão nosso olhar ao longo do exercício de análise, procurando analisar os enunciados definitórios a partir das condições de produção imbricadas no instrumento linguístico, sem com isso estabelecer correspondências simplistas como as apontadas pelos autores.

Independentemente da formulação adotada em sua elaboração, todo dicionário traça "uma espécie de cartografia dos significados das palavras" (COLLINOT; MAZIÈRE, 1997, p. 129), o que, ao mesmo tempo que determina as formas atuais, possibilita também as formas de entradas futuras. Junto a essa generalização, os autores apontam quatro teses sobre o funcionamento do discurso lexicográfico. A primeira é que ele não é interpretável em termos de metalinguagem e é constituído segundo um molde. A segunda é que a propriedade de reflexividade da língua e do discurso sobre eles mesmos é o que faz com que todo discurso e unidade de discurso sejam interpretáveis. A terceira é que "toda manifestação do sentido é da ordem de um discurso" (COLLINOT; MAZIÈRE, 1997, p. 131), e é pela possibilidade de transferência de um discurso a outro que são possíveis a

\footnotetext{
${ }^{1}$ Uma vez que, no Brasil, o campo da História das Ideias Linguísticas se desenvolveu em conjunto com os estudos do discurso, nos valemos desta noção da Análise do Discurso de linha materialista. Assim, compreendemos a Formação Discursiva como um determinante para a produção e compreensão de sentidos.

${ }^{2}$ Os autores salientam que, embora Pêcheux afirme que patrões e operários não falam a mesma língua, isso não deve ser interpretado de forma linguística, mas, sim, política.
} 
leitura e a escrita do sentido. Finalmente, a quarta tese afirma que toda significação é regulada por um agenciamento de enunciados em rede, motivo pelo qual todo gesto de discriminação de dada forma de significação é ao mesmo tempo um evento linguístico e um evento discursivo.

Finalmente, mantemos de Collinot e Mazière (1997) que o dicionário é um discurso feito do eco de outros discursos. Assim, os autores afirmam que, se nenhum discurso é transparente, a materialidade das definições num dado dicionário tem algo a dizer sobre as representações culturais e sobre o lugar do lexicógrafo na ordem do saber. $\mathrm{Na}$ análise aqui desenvolvida, isso se mostra especialmente interessante quando da observação das variações nas definições seja entre dicionários de língua, seja entre dicionários especializados.

\section{VERBETE GÊNERO NOS DICIONÁRIOS 3.1 A CONSTRUÇÃO DO CORPUS}

Para o desenvolvimento da análise, foram selecionados, a princípio, quatro dicionários de língua diferentes, dois consultados em ambiente digital e dois consultados em sua versão impressa: os dicionários digitais Michaelis ${ }^{3}$ e Caldas Aulete ${ }^{4}$ e os dicionários impressos Dicionário Escolar da Língua Portuguesa (2008), de autoria da Academia Brasileira de Letras, e Dicionário Houaiss da Língua Portuguesa (2009), de autoria de Antônio Houaiss e Mauro de Salles Villar.

Após consultarmos o verbete gênero nos quatro dicionários, constatamos que em apenas um deles, o Caldas Aulete, uma das acepções apresentadas diz respeito à identidade de gênero. Nos demais dicionários, as definições retomam conhecimentos da biologia, da gramática, das artes plásticas, da literatura, entre outros campos de saber especializados, sem tocar em questões como diferença sexual e subjetividade. Esse silenciamento nos fez percorrer um novo percurso para a construção do corpus. Ao invés de começar um novo corpus desconsiderando o descarte desses três dicionários ${ }^{5}$, consideramos importante manter a referência a eles para salientar a ausência dessa acepção nas definições de seus verbetes. São dicionários populares que não abordam uma acepção bastante recorrente da palavra gênero, embora abordem acepções extremamente especializadas, como no caso dicionário Michaelis, que, em sua última acepção para gênero apresenta: "Na teoria grega, modo de distribuição dos intervalos dentro de um tetracorde".

\footnotetext{
${ }^{3}$ Disponível em: https://michaelis.uol.com.br/. Acesso em: 10 ago. 2018.

${ }^{4}$ Disponível em: http://www.aulete.com.br/. Acesso em: 10 ago. 2018

${ }^{5}$ Quanto ao dicionário Houaiss, ele apresenta em sua versão online, que pode ser consultada em: https://houaiss.uol.com.br/, uma acepção de gênero que não consta na versão impressa. "13 soc construção cultural das diferenças sexuais entre homens e mulheres". No entanto, considerando que nosso foco ao consultar o Houaiss era analisá-lo como dicionário impresso, e que seu acesso em versão online é restrito (limitado a assinantes do Uol), optamos por não incluir essa atualização do verbete em nossa análise. Desse modo, quando nos referimos ao dicionário Houaiss neste artigo, estamos considerando sua edição impressa de 2009.
} 
A inexistência dessa acepção nos três dicionários nos conduziu à reflexão desenvolvida por Orlandi (2007) sobre as formas do silêncio. A autora afirma que o silêncio significa em modos próprios e traça uma relação com a polissemia: "É a incompletude que produz a possibilidade do múltiplo, base da polissemia. E é o silêncio que preside essa possibilidade" (ORLANDI, 2007, p. 47). Uma vez que as definições do dicionário linearizam a polissemia, organizando as acepções possíveis para uma palavra, é pertinente destacar o funcionamento do silêncio nessa mediação. Orlandi estabelece duas categorias para o silêncio: o silêncio fundante e a política do silêncio (ou silenciamento):

\begin{abstract}
A primeira nos indica que todo processo de significação traz uma relação necessária ao silêncio; a segunda diz que - como o sentido é sempre produzido de um lugar, a partir de uma posição do sujeito -, ao dizer, ele estará, necessariamente, não dizendo "outros" sentidos. Isso produz um recorte necessário no sentido. Dizer e silenciar andam juntos. (ORLANDI, 2007, p. 53)
\end{abstract}

O que pudemos identificar na primeira leitura dos três dicionários foi $o$ funcionamento da segunda categoria de silêncio, o silenciamento: diversas acepções de gênero são apresentadas (no Michaelis, 13; no Dicionário Escolar da Língua Portuguesa, 9; no Houaiss, 16), enquanto uma delas, a que se refere à identidade de gênero, é silenciada. Orlandi afirma que a dimensão política do silêncio ${ }^{6}$ consiste no fato de ele recortar o dizer, e a omissão dessa acepção nas obras consultadas levanta questões como a hierarquização das acepções (o gênero como classe gramatical, por exemplo, foi uma acepção encontrada em todos os dicionários de língua consultados) e mesmo o jogo de forças materializado nos instrumentos linguísticos: na seara dos conhecimentos específicos, o saber metalinguístico seria mais relevante para um consulente projetado que o saber antropológico?

Uma vez descartados três dos dicionários, reorganizamos o corpus tendo em vista duas questões. A primeira é que todos os dicionários consultados traziam uma acepção voltada ao gênero gramatical; este, por sua vez, recentemente passou a ser questionado através do argumento de uma não correspondência com a identidade de gênero e os processos de subjetivação. Foi por isso que incluímos em nosso corpus um dicionário especializado de linguística e gramática. A segunda questão diz respeito à inclusão de outro dicionário especializado: como a única referência à acepção de gênero que procuramos, apresentada no Caldas Aulete, estava sob a legenda da Antropologia, um campo das Ciências Humanas, recorremos a um dicionário especializado de Ciências Humanas $^{7}$ para analisar o verbete gênero.

\footnotetext{
${ }^{6}$ Para a autora, tal dimensão se divide em silêncio constitutivo, que diz respeito ao fato de que para dizer algo é preciso calar outras coisas, e silêncio local, que funciona mediante algum tipo de censura. Compreendemos que o silenciamento que se dá na constituição dos dicionários é o constitutivo, determinado pelas condições de produção.

${ }^{7}$ Destacamos que nem todos os dicionários especializados no campo de Ciências Humanas apresentam a entrada gênero. A obra Palavras-chave: um vocabulário de cultura e sociedade, de Raymond Williams (2007), por exemplo, apresentando os termos a partir de sua origem, utilização e diferenciações acadêmicas, conta com o verbete sexo, no qual especifica que a utilização de gênero teria relação com associações teóricas elaboradas ao longo do século XX.
} 
Quanto aos dicionários especializados, Nunes (1996) destaca em sua tese a costumeira divisão entre "dicionários de língua" e "dicionários de coisa". Nos dicionários analisados pelo autor, produzidos entre os séculos XVI e XIX, nem sempre essa distinção se dava de modo claro. No entanto, o autor descreve a passagem que se deu dos dicionários enciclopédicos aos dicionários de língua, exemplificando com as diferenças entre o dicionário de Moraes (1789) e o de Bluteau (1712/1728): a diminuição da extensão da definição marca a transição de um tipo de dicionário para outro. Se atualmente tanto os dicionários especializados quanto os dicionários de língua são bem definidos enquanto tais, a extensão característica da definição em cada tipo se mantém: a definição de gênero no dicionário de Ciências Humanas, por exemplo, ocupa três páginas, apresentando inclusive um texto secundário à parte da definição ${ }^{8}$.

Para configurar o corpus com dois dicionários especializados e dois dicionários de língua, selecionamos um dicionário de língua, além do Caldas Aulete, que apresentasse a acepção de gênero que pretendíamos analisar. Foi assim que nosso corpus final de análise passou a contar com as seguintes obras:

\begin{tabular}{|l|l|}
\hline Dicionários de língua & Dicionários especializados \\
\hline $\begin{array}{l}\text { AULETE, Caldas. Aulete Digital - o dicionário } \\
\text { da língua portuguesa na internet. Dicionário } \\
\text { Caldas Aulete, versão online. }\end{array}$ & $\begin{array}{l}\text { CÂMARA JUNIOR, Joaquim Mattoso. } \\
\text { Dicionário de linguística e gramática: referente } \\
\text { à língua portuguesa. 28. ed. Petrópolis, RJ: } \\
\text { Vozes, 2011. }\end{array}$ \\
\hline $\begin{array}{l}\text { FERREIRA, Aurélio Buarque de Holanda. Novo } \\
\begin{array}{l}\text { Aurélio Século XXI: o dicionário da língua } \\
\text { portuguesa. 5. ed. Rio de Janeiro: Nova Fronteira, } \\
2010\end{array}\end{array}$ & $\begin{array}{l}\text { Dicionário de ciências humanas/direção de } \\
\text { Jean-François Dortier; revisão e coordenação da } \\
\text { tradução Márcia Valéria Martinez de Aguiar - } \\
\text { São Paulo: Editora WMF Martins Fontes, 2010. }\end{array}$ \\
\hline
\end{tabular}

\section{Quadro 1 - Dicionários selecionados como corpus}

Fonte: Elaborado pela autora.

Uma vez apresentados os critérios e procedimentos de construção do corpus, passamos a uma apresentação dos dicionários selecionados, com vistas a situá-los espaçotemporalmente em suas condições de produção.

$\mathrm{Na}$ página inicial do Aulete Digital, o dicionário é apresentado resumidamente como "o dicionário da língua portuguesa na internet/ Mais de 818 mil verbetes, definições e locuções em permanente atualização. Um dicionário de crescimento infinito, sempre em interação com a língua portuguesa". Isso vai ao encontro do que Oliveira (2006, p. 86) explica sobre a compra do dicionário pelo Grupo Educacional Positivo em 2003, com a proposta de "formar um corpus da língua portuguesa com abrangência internacional para derivar em produtos lexicográficos diversos, dentre os quais um monolíngue eletrônico com atualização permanente". A autora ressalta que esse formato muda a relação entre o falante e o instrumento linguístico: "o falante passa a ocupar um lugar de

\footnotetext{
${ }^{8}$ Por esse motivo, os verbetes dos dicionários especializados não constarão integralmente neste artigo, sendo apresentados apenas os trechos que forem analisados, com as supressões sinalizadas por “[...]".
} 
saber em relação ao instrumento." (OLIVEIRA, 2006, p. 86). Relacionamos essa mudança ao já citado apontamento de Collinot e Mazière (1997) sobre o lugar de saber do lexicógrafo: considerando um formato em que o consulente tem a possibilidade de interagir, é pertinente questionar o quanto essa interação pode repercutir nas condições de produção, uma vez que mais de um lugar de saber passa a coexistir. O conhecimento metalinguístico de um lexicógrafo não é o mesmo de um falante comum; no entanto, é a esse falante comum que o trabalho do lexicógrafo se dirige, ao mesmo tempo que pode dele receber sugestões. Ainda que a relação deixe de ser unilateral, numa espécie de autoria coletiva, esse compartilhamento é assimétrico, visto que é ainda ao lexicógrafo que cabe a legitimação dos sentidos que figurarão no dicionário, contrariamente ao que acontece com outras ferramentas de conhecimento no ambiente digital, como, por exemplo, a Wikipédia.

Na sequência há uma apresentação dos dois módulos do dicionário: “1. O tradicional e respeitadíssimo Dicionário Caldas Aulete em sua versão original, atualizada para o Brasil até a década de 1980, com mais de 200 mil verbetes (os verbetes desse módulo são identificados com o registro de 'verbete original')". Essa descrição demonstra o pertencimento do dicionário a um português específico, falado no Brasil, e historicamente contextualizado, com registros que datam de 1980. Além disso, a atualização "para o Brasil" diz respeito à produção inicial do dicionário: sua primeira edição impressa, que data de 1986, foi inicialmente elaborada e publicada em Portugal, com a proposta de ser um dicionário canônico, que homogeneizasse a língua portuguesa (SILVERIS, 2018). Embora o dicionário eletrônico tenha sido consultado no ano de 2018, não há indicação nos verbetes ou nas seções gerais sobre a data de registro e atualização de cada entrada. O funcionamento é diferente nos dicionários impressos, que apresentam o ano da edição na ficha catalográfica.

É o caso do Dicionário Aurélio, cuja edição consultada para este artigo data de 2010. Esta é a quinta edição do dicionário, cujo prefácio explica que a edição anterior fora voltada à atualização dos verbetes segundo o acordo ortográfico que passou a vigorar no Brasil em 2009, enquanto a atual, após essas alterações, foi "revista, atualizada e acrescida com milhares de vocábulos de diversas áreas do conhecimento", além de trazer "um amplo registro de vocábulos e termos de cunho internacional, ora aportuguesados, ora com a grafia original, conforme o uso que, geralmente, se faz deles". O objetivo final da edição é que seja "útil e prática".

Esse prefácio é seguido pelos prefácios à quarta, terceira e segunda edições, todos voltados a explicações sobre mudanças e acréscimos. O prefácio que se volta aos objetivos do dicionário é o Prefácio à Primeira Edição, no qual o autor (FERREIRA, 2010) afirma que "pretendeu-se fazer um dicionário médio, ou inframédio etimológico, com razoável contingente vocabular", dando importância à atualização, à língua que circula na mídia (não restrita à literatura), "ao falar do povo" e aos "linguajares diversos". Essa pretensão parece se manter até a edição mais recente, publicada anos após a morte de seu autor, haja vista a inclusão de verbetes com foco na realidade contemporânea. Ao longo do prefácio são apresentadas especificações sobre o modo de apresentação dos verbetes e os pontos que neles foram priorizados (como a sinonímia e a regência verbal). Entre eles, destacamos um que se justifica pelas necessidades do público projetado: "Parece-nos de incontestável utilidade para o leitor o largo registro que fizemos de 
elementos de composição, vernáculos e de origem latina e grega", dialogando com a pretensão de utilidade e praticidade manifesta no prefácio da quinta edição. É com essas especificações que se encerram as orientações ao consulente e as descrições a respeito do público projetado.

O Dicionário de Linguística e Gramática: referente à língua portuguesa (doravante DLG) selecionado para esta análise teve sua primeira edição em 1956. De autoria de Joaquim Mattoso Camara Jr. (que, de acordo com o texto que consta na orelha do dicionário, é conhecido como "Pai da Linguística no Brasil"), teve como título inicial Dicionário de Fatos Gramaticais. A partir da segunda edição, até a sexta, seu título foi Dicionário de Filologia e Gramática. O título atual foi adotado após a morte do autor, por decisão dos editores que assinam a Nota dos Editores para a $7^{\mathrm{a}}$ Edição, após consulta ao linguista Gomes de Matos, que resenhara a $2^{a}$ edição da obra em 1966. A justificativa para a mudança é a maior abrangência e difusão da Linguística em relação à Filologia no Brasil. Junto a isso, a nota dos editores destaca que não há redundância na sequência "Linguística e Gramática", posto que a Linguística, conforme Gomes de Matos, é a "verdadeira ciência panssemiótica do comportamento humano", enquanto a gramática figura como um estudo descritivo e/ou explicativo dos funcionamentos formais de uma língua.

Desse percurso, destacamos a manutenção do saber gramatical no título da obra ao longo das mudanças: começando com foco nos fatos gramaticais, a obra passou a circular como um dicionário também de filologia, para finalmente se consolidar (nas 21 edições seguintes) como um compêndio de linguística e gramática. As mudanças nos títulos foram acompanhadas por mudanças no conteúdo do dicionário e podem ser relacionadas ao conhecimento metalinguístico e gramatical no Brasil: enquanto a gramática se mantém como um campo do conhecimento que atravessa gerações, a filologia e a linguística são negociáveis. O conhecimento metalinguístico, como observamos pela marcação da acepção gramatical de gênero em todos os dicionários consultados, ocupa lugar permanente nos dicionários de língua e é passível de ter um dicionário consagrado a ele.

O objetivo do DLG é definido como "o estudo da Língua Portuguesa" e relacionase às últimas explicações do dicionário, onde este "se entrega à consulta do público estudioso brasileiro". Além disso, uma orientação de uso estabelece que:

\footnotetext{
Caberá à exação do consulente aproveitar ao máximo essa disposição da matéria, ampliando a sua consulta por todos os verbetes assim relacionados e indo de remissão em remissão até chegar a um informe compreensivo e conclusivo, em vez de contentar-se com os dados parciais e incompletos do verbete a que por acaso se tenha circunscrito. (CÂMARA JUNIOR, 2011, p. 37).
}

O público projetado pode ser interpretado não como um falante comum de língua portuguesa, mas como um estudioso da língua portuguesa. Este, por sua vez, não fará uma consulta simples a fim de sanar uma dúvida, mas deverá ampliar sua pesquisa a todos os verbetes relacionados àquele que inicialmente consultou. Pode-se observar, desde o público projetado, uma diferença em relação aos dicionários de língua: enquanto estes se destinam à resolução de dúvidas pontuais a respeito da língua, os especializados se apresentam como uma fonte de pesquisa mais aprofundada. 
O segundo dicionário especializado que analisamos, Dicionário de Ciências Humanas (doravante DCH), é de autoria de Jean-François Dortier e foi escrito originalmente em língua francesa. Sua tradução foi publicada no âmbito do Ano da França no Brasil e do programa de apoio à publicação Carlos Drummond de Andrade, com apoio do Ministério Francês das Relações Exteriores. A folha de rosto indica que alguns verbetes passaram por "adaptação ou reformulação" (o verbete gênero não é um deles) e identifica o responsável em cada caso. A tradução do $\mathrm{DCH}$, por sua vez, é atribuída a seis diferentes tradutores, seguidos de uma revisora e coordenadora da tradução, não havendo identificação da tradução de cada verbete por algum dos tradutores citados. O prefácio que consta antes dos verbetes é uma tradução do prefácio de Dortier, não havendo um texto introdutório voltado especificamente à tradução.

No prefácio (DORTIER, 2010), o objetivo do DCH é apresentado como "colocar ao alcance de um grande público os conceitos, os autores e as teorias que formam o corpo atual das ciências humanas". Esse grande público, em seguida, é especificado como estudantes, pesquisadores e professores de ciências humanas, focando na interdisciplinaridade que é exigida nessa formação. Assim, o dicionário "oferece um meio de circular não apenas de uma especialidade a outra, mas também de abordar os inúmeros conceitos e campos de pesquisa que atravessam alegremente as fronteiras disciplinares". A menção aos pesquisadores e estudantes permite interpretar que esse dicionário não seja voltado ao público comum que porventura queira se informar sobre algum termo ouvido na mídia (exemplo fornecido pelo próprio $\mathrm{DCH}$ ).

Nesse sentido, os dois dicionários especializados analisados neste artigo se assemelham no público projetado. No entanto, algumas diferenças se marcam (justificadas talvez pelas condições de produção, que determinam diferentes modos de relação com o conhecimento, seja metalinguístico ou não, de cada país). É o caso, por exemplo, da ausência de uma contextualização sobre a autoria do DCH: Dortier aparece como responsável pela direção, sem especificar se foi ele quem elaborou as definições e selecionou os verbetes ou quais critérios foram adotados para isso. Além disso, o DLG conta com uma extensa apresentação do autor, com detalhes sobre sua formação acadêmica e sobre suas demais publicações, diferentemente do $\mathrm{DCH}$, que não apresenta qualquer informação sobre o responsável por sua direção. Enquanto as notas do dicionário especializado em linguística e gramática dissertam sobre o processo de elaboração da obra, o dicionário especializado em ciências humanas apresenta uma reflexão focada na relação da publicação com as necessidades contemporâneas dos especialistas da área.

Uma vez apresentados os dicionários, passamos à análise do verbete gênero em cada um deles.

\subsection{GÊNERO NOS DICIONÁRIOS DE LÍNGUA}

Antes de procedermos à análise dos verbetes, recorremos à pesquisa de Oliveira (2006) para traçar um paralelo quanto a uma particularidade da palavra aqui analisada. Buscando compreender os sentidos da palavra cidadania, a autora se voltou à textualidade 
de dicionários brasileiros e lusitanos do século XVIII ao século XXI. Sua análise nos serve de base porque, assim como a análise aqui proposta, é centrada em "uma palavra que não tem como contraparte no mundo um objeto concreto, uma palavra do domínio político, cujos sentidos se buscam frequentemente em textos especializados, da filosofia ou da história política" (OLIVEIRA, 2006, p. 11). Apesar das diferenças quanto às áreas de conhecimento elencadas pela autora, gênero também é uma palavra frequentemente evocada em textos especializados, além de não fazer referência a um objeto no mundo, mas a uma noção teórica. Essa distinção nos conduz a pensar, mais uma vez, sobre a diferença entre a palavra e o conceito e, mais do que isso, sobre as relações de polissemia que atravessam as palavras, como a autora observa:

\begin{abstract}
[...] a palavra cidadania deriva sim de cidadão, porém não do seu sentido greco-romano, mas do sentido moderno, oriundo da Revolução Francesa. Desse modo, não foram os antigos que "inventaram o conceito", ainda que tenham significado no tempo a "condição de cidadão", enunciado que tomamos hoje por paráfrase de cidadania. A ideia de "inventar o conceito", aliás, dá margem a uma interpretação que fixa os sentidos no étimo. O que venho afirmando aqui se opõe a essa posição. Pretendo mostrar no dicionário justamente que a palavra cidadania é polissêmica e que seus sentidos se constituem na história de suas enunciações ao longo do tempo. (OLIVEIRA, 2006, p. 38).
\end{abstract}

Essas relações se marcam de modo bastante significativo em algumas das definições aqui analisadas, que permitem refletir sobre as diferenças entre palavra e conceito. Buscando articular o estudo dos enunciados dos dicionários, que organizam acepções possíveis para dado verbete, a uma compreensão discursiva dos efeitos de sentido, identificamos um movimento de estabilização, dada pela linearização das acepções frente aos diferentes sentidos que uma palavra pode assumir, a depender do campo de conhecimento no qual é mobilizada.

Além da pesquisa de Oliveira (2006), destacamos da já citada pesquisa de Nunes (1996) algumas observações sobre o enunciado definidor. Para o autor, "a variação formal do enunciado definidor nos dicionários não é indiferente quanto aos efeitos de sentido que seu discurso produz" (NUNES, 1996, p. 187), e é por isso que sua análise do enunciado definidor se baseia nas variações que se estabelecem a partir de um formato padrão. Tal formato, sintetizado por Mazière (1989) e citado por Nunes (1996), é o seguinte:

N-Entrada: N-Cabeça (Adjetivo) (Particípio) (S Prep.) (Relativa) (Circunstancial)

Para o autor, a análise dos variados desdobramentos possíveis a partir desse padrão permite depreender o funcionamento discursivo das definições, bem como os processos de referenciação que são postos em jogo (NUNES, 1996). Essas orientações nos servirão de base para a análise do verbete gênero nos dicionários selecionados, como segue: 


\begin{tabular}{|l|}
\hline Dicionário Caldas Aulete \\
\hline gênero \\
(gê.ne.ro) \\
sm. \\
1. Conceito que engloba todos os grupos com \\
características básicas comuns (espécies) num universo \\
ou classe de seres ou coisas \\
2. P.ext. Conjunto de seres ou coisas que têm a mesma \\
origem ou que se encontram ligados pela semelhança \\
de suas principais características: o gênero humano. \\
3. Espécie, tipo: Ele gosta de todo o gênero de pessoas. \\
4. Biol. Categoria taxonômica de animais ou vegetais \\
que se situa abaixo de família e acima de espécie \\
5. Gram. Categoria gramatical que classifica nomes e \\
pronomes de uma língua, distinguindo-os, p.ex., entre \\
masculino, feminino e neutro
\end{tabular}

6. Liter. Categoria distintiva de composição literária: $\mathrm{O}$ romance é um gênero literário; a poesia, outro.

7. Art.Pl. Cin. Natureza do assunto tratado por um artista: filme do gênero romântico.

8. Antr. A forma que a diferença sexual assume, nas diversas sociedades e culturas, e que determina os papéis e o status atribuídos a homens e mulheres e a identidade sexual das pessoas

9. Ret. Divisão dos discursos conforme os fins a que se propõem e os meios que empregam para tal

[F.: Do lat. genus,eris]
Dicionário Aurélio

gênero.

[Do lat. genus, eris, 'classe', 'espécie', poss. pelo pl. lat. genera, ou pelo lat. * generum, com mud. de declinação.]

S. m.

1. Lóg. Classe cuja extensão se divide em outras classes, as quais, em relação à primeira, são chamadas espécies.

2. Lóg. Um dos predicáveis (q.v.): característica(s) que uma coisa tem em comum com outra, e que lhe(s) determina $(\mathrm{m})$ a essência, quando acrescida da diferença (8). [Cf. nesta acepç., classe (22).]

3. P. ext. Qualquer agrupamento de indivíduos, objetos, fatos, ideias, que tenham caracteres comuns; espécie, classe, casta, variedade, ordem, qualidade, tipo. Frequentava todo gênero de gente; Que gênero de conversa é esta? Nesta rua há todo gênero de casas.

4. Maneira, modo, estilo: Não concordo com esse gênero de vida.

5. Nas obras de um artista, de uma escola, cada uma das categorias que, por tradição, se definem e classificam segundo o estilo, a natureza ou a técnica: os gêneros literários, musicais, pictóricos.

6. Classe ou natureza do assunto abordado por um artista: gênero dramático, gênero romântico.

7. Antrop. A forma culturalmente elaborada que a diferença sexual toma em cada sociedade, e que se manifesta nos papéis e status atribuídos a cada sexo e constitutivos da identidade sexual dos indivíduos.

8. Biol. Categoria taxonômica compreendida entre a família e a espécie. [V. grupos taxonômicos].

9. E. Ling. Categoria gramatical (q.v.) que dispõe os nomes de uma língua em classes (como feminino, masculino, neutro, animado, inanimado), de acordo com (a) a referência pronominal (a casa/ela; o menino/ele); (b) a concordância com os modificadores (a menina bonita/o gato gordo); (c) a presença de determinados afixos (como, p. ex., -triz).

10. Mat. Diferença entre o número máximo de pontos duplos que uma curva unicursal pode ter e o número dos que ela realmente possui; deficiência.

11. Mat. Metade do número de cortes que devem ser feitos em uma superfície para que ela se torne simplesmente conexa. $\sim$ V. gêneros.

Gênero de vida. Conjunto de atividades habituais, provenientes da tradição, mercê das quais o homem assegura a sua existência, adaptando a natureza em seu proveito.

Gênero humano. A espécie humana; a humanidade.

Comum de dois gêneros. E. Ling. V. comum-de-dois.

Fazer gênero. Bras. Gír. Fingir ser o que não é.

Não fazer o gênero de. Bras. Não estar conforme a opinião ou gosto de (alguém); não agradar a.

\section{Quadro 2 - Gênero para os dicionários de língua}

Fonte: Elaborado pela autora com base em Aulete (2018) e Ferreira (2010). 
Ainda que o número de acepções seja aproximado entre os dois dicionários, os enunciados apresentados no Caldas Aulete são mais enxutos, enquanto no Aurélio as definições são mais extensas e dispõem de mais exemplos. A estrutura da definição é semelhante em ambos os dicionários: as acepções alternam entre a fórmula "X que $Y$ " (por exemplo, "Conjunto de seres ou coisas que têm a mesma origem ou que se encontram ligados pela semelhança de suas principais características", no Caldas Aulete, e "Qualquer agrupamento de indivíduos, objetos, fatos, ideias, que tenham caracteres comuns", no Aurélio) e o uso do particípio (por exemplo, "Natureza do assunto tratado por um artista", no Caldas Aulete, e "Categoria taxonômica compreendida entre a família e a espécie", no Aurélio). O tempo verbal predominante nos enunciados é o presente, tanto no modo indicativo como no subjuntivo, conforme grifos dos exemplos anteriores.

Quanto à organização das acepções, destacamos que no Caldas Aulete apenas a partir da terceira acepção o conhecimento especializado passa a ser marcado por rubricas como "Biol.", "Gram.", enquanto no Aurélio a primeira acepção já remete ao campo de conhecimento da Lógica. Nesse sentido, é possível afirmar que o dicionário Aurélio toma os diferentes campos de conhecimento especializados como percurso inicial para os sentidos de gênero, visto que só a partir da terceira acepção a definição não é marcada por uma rubrica de especificidade. O movimento do Caldas Aulete, ao contrário, parte do conhecimento geral para o específico, e não inclui nesse específico as acepções referentes à lógica e à matemática, por exemplo, presentes no Aurélio. Este, por sua vez, não inclui a acepção referente à retórica, presente no Caldas Aulete.

Veremos agora como a acepção de gênero que diz respeito à diferença sexual é apresentada em ambos os dicionários.

\begin{tabular}{|l|l|}
\hline Dicionário Caldas Aulete & Dicionário Aurélio \\
\hline $\begin{array}{l}\text { 8. Antr. A forma que a diferença sexual assume, nas } \\
\text { diversas sociedades e culturas, e que determina os } \\
\text { papéis e o status atribuídos a homens e mulheres e à } \\
\text { identidade sexual das pessoas }\end{array}$ & $\begin{array}{l}\text { 7. Antrop. A forma culturalmente elaborada que a } \\
\text { diferença sexual toma em cada sociedade, e que se } \\
\text { manifesta nos papéis e status atribuídos a cada sexo e } \\
\text { constitutivos da identidade sexual dos indivíduos. }\end{array}$ \\
\hline
\end{tabular}

\section{Quadro 3 - Acepção específica de gênero para os dicionários de língua}

Fonte: Elaborado pela autora com base em Aulete (2018) e Ferreira (2010).

Podemos identificar semelhanças desde a rubrica que categoriza as definições, diferentemente do que acontece, por exemplo, quanto ao gênero gramatical (categorizado num dicionário sob a rubrica da Gramática e em outro sob Estudos Linguísticos): em ambos os dicionários é a Antropologia que categoriza a definição da identidade sexual. Esta, por sua vez, em ambos os dicionários, é relacionada com "sociedade", "cultura", "papéis" e "status". Um olhar mais atento à sintaxe dos enunciados permite identificar diferenças sutis, mas relevantes, entre as definições.

No dicionário Aurélio, a relação entre gênero e cultura está posta desde a primeira linha, visto que "a forma" é "culturalmente elaborada": "A forma culturalmente elaborada que a diferença sexual toma em cada sociedade, e que se manifesta nos papéis e status atribuídos a cada sexo e constitutivos da identidade sexual dos indivíduos". No Caldas Aulete, embora a cultura esteja presente na definição "A forma que a diferença sexual 
assume, nas diversas sociedades e culturas, e que determina os papéis e o status atribuídos a homens e mulheres e à identidade sexual das pessoas", a formulação sintática não permite que ela figure como agente responsável pela elaboração da diferença sexual: a cultura, pluralizada em "nas diversas sociedades e culturas", figura como adjunto adverbial, lugar onde a assunção ocorre. Vale destacar que a forma tomada pela diferença sexual está posta no Aurélio como elaboração, assemelhando-se a um processo, enquanto no Caldas Aulete a diferença sexual tem uma forma assumida (sem especificação de como se assume). Desse cotejamento entre os primeiros fragmentos das definições, é possível concluir que o Aurélio permite a leitura do gênero como um processo relacionado à diferença sexual e dependente da cultura, enquanto o Caldas Aulete não apresenta explicações sobre a forma como a diferença sexual é assumida, pontuando a cultura simplesmente como o ambiente onde essa assunção ocorre.

$\mathrm{Na}$ segunda parte dos enunciados, embora os "papéis e status atribuídos" estejam presentes em ambas as definições, a relação deles com a forma tomada pela diferença sexual é apresentada de modos diferentes. Para o Caldas Aulete, a forma que a diferença sexual assume determina esses papéis e status; para o Aurélio, os papéis e status são um local de manifestação dessa diferença sexual, não se atribuindo um sentido de causalidade por eles, como é possível interpretar pela determinação apresentada no Caldas Aulete. Essa determinação se estende à identidade sexual das pessoas, de modo que esta é determinada da mesma forma que os papéis e o status. Já para o Aurélio, a identidade sexual estabelece uma outra relação: ela é constituída pelos papéis e status atribuídos a cada sexo, permitindo uma interpretação sequencial: a cultura elabora a diferença sexual, a diferença sexual se manifesta nos papéis e status atribuídos a cada sexo e os papéis e status constituem a identidade sexual.

Após o cotejamento entre as definições, consideramos que ambas se centram sobre a diferença sexual e a identidade sexual, tendo as principais diferenças marcadas pelas relações que estabelecem com os elementos que as circundam, conforme as figuras 1 e 2:

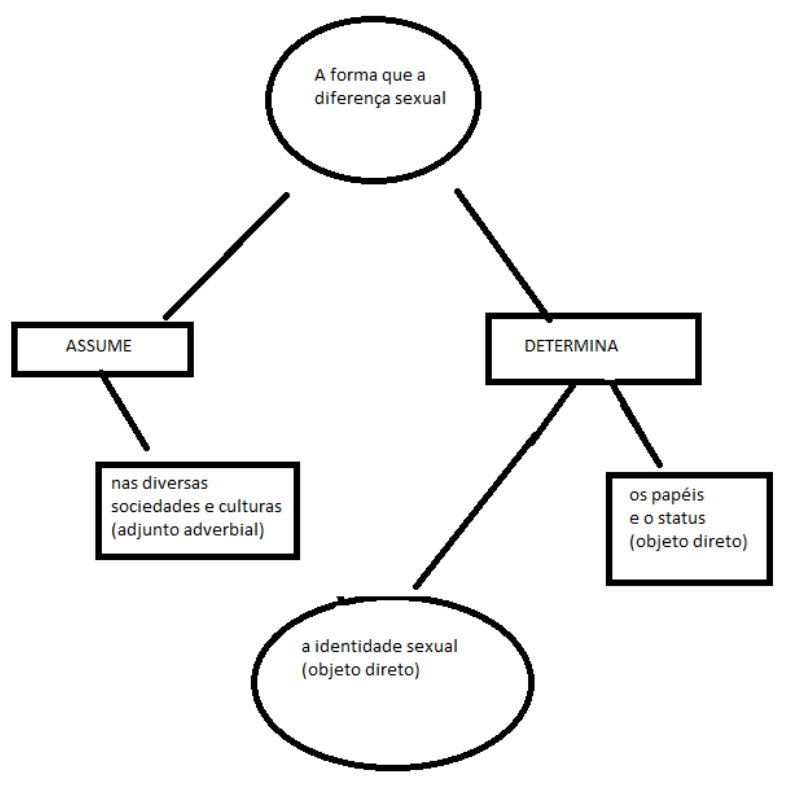

Figura 1 - Gênero no dicionário Caldas Aulete

Fonte: Elaborada pela autora com base em Aulete (2018). 


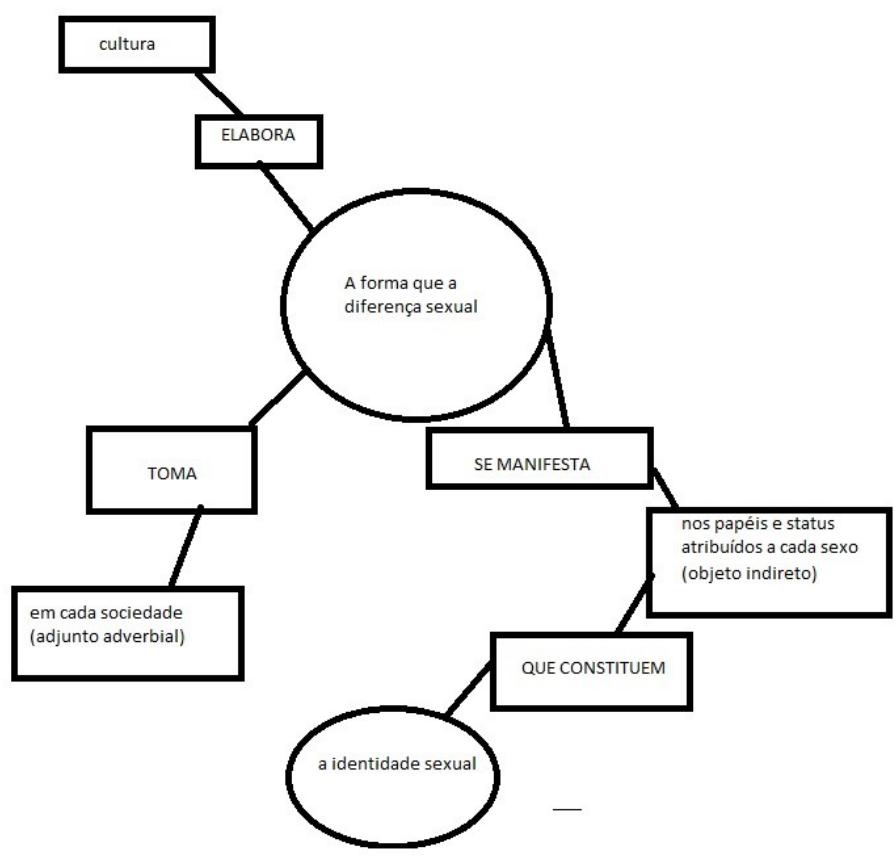

Figura 2 - Gênero no dicionário Aurélio

Fonte: Elaborado pela autora com base em Ferreira (2010).

Os círculos representam os núcleos das definições, em torno dos quais se organizam os elementos complementares (alguns dos particípios e substantivos derivados foram substituídos por sua forma verbal para permitir uma melhor visualização das relações estabelecidas). As figuras ilustram as relações sintáticas das diferentes definições. Dentre eles, destacamos que, na Figura 1, a identidade sexual está na mesma posição de "os papéis e o status", numa relação de paridade; na Figura 2, esses papéis funcionam como agente de constituição da identidade sexual, o que reforça a já comentada ênfase da definição aureliana de gênero como um processo, com desdobramentos identificáveis e interligáveis.

Nesse sentido, é possível afirmar que a acepção de gênero para o dicionário Aurélio estabelece, de uma forma mais explícita do que a apresentada no dicionário Caldas Aulete, o modo como ele é elaborado pela cultura a partir da diferença sexual e, a partir daí, de modo sequencial, produz efeitos na identidade sexual. No Caldas Aulete, diferentemente, a identidade sexual é determinada no mesmo nível dos papéis e status que são atribuídos a homens e mulheres.

Uma vez analisados os diferentes efeitos de sentido produzidos pelos enunciados definidores aparentemente semelhantes em dicionários de língua, passamos agora à análise dos dicionários especializados. 
Para proceder à análise do verbete gênero no Dicionário de Linguística e Gramática (doravante DLG), dada a extensão do verbete, trazemos aqui apenas os fragmentos que serão analisados (as supressões estão marcadas por [...]).

GÊNERO - Categoria gramatical por que nas línguas indo-europeias se distribuem os nomes (v.) em 3 ou 2 classes: 1) masculino, feminino, neutro; 2) masculino, feminino. A primeira divisão, tripartida, é a das antigas línguas clássicas, entre as quais o latim. A segunda, bipartida, é a das línguas românicas, derivadas do latim, entre as quais o português. $\mathrm{O}$ critério da primeira divisão parece ter decorrido de uma divisão anterior entre gênero ANIMADO (depois desdobrado em masculino e feminino) e INANIMADO (neutro). Era uma concepção mística, cujo sentido já no latim clássico tinha em grande parte desaparecido. A divisão bipartida das línguas românicas abrange todos os substantivos e os adjetivos que entram em concordância (v.) com eles. O significado da categoria é variável e até lábil; a distinção dos sexos é um significado da categoria para os nomes de seres do reino animal, mas mesmo aí há nomes que só têm um gênero, independentemente do sexo (ex.: cônjuge, masculino; testemunha, feminino; jacaré, masculino; cobra, feminino), podendo o sexo ser indicado subsidiariamente pelos termos macho e fêmea apostos ao nome e sem concordância de gênero com ele, no caso de animais irracionais - um jacaré fêmea, uma cobra macho (nomes EPICENOS).[...] Para substantivos referentes a seres do reino animal encontramse não raro vocábulos diferentes para o masculino e feminino, como formas supletivas (v.): a) formados de semantemas distintivos (ex.: homem - mulher; bode - cabra); b) diferenciados por um sufixo lexical, na base de um mesmo semantema, podendo ter ou não o feminino a desinência - a (conde - condessa, com o masculino sem sufixo lexical e o feminino com o sufixo -essa provido da desinência - $a$; imperador-imperatriz, com os sufixos lexicais -dor e-triz para o masculino e o feminino, respectivamente, e sem a desinência $-a$ no feminino). [...]

\section{Quadro 4 - Gênero no Dicionário de Linguística e Gramática}

Fonte: Elaborado pela autora com base em Camara Junior (2011).

A definição inicial de gênero é "categoria gramatical", o que nos remete à já observada regularidade pela qual os sentidos de categorias, de classes, de identidades e/ou diferenças são constitutivos das diferentes acepções de gênero. Destacamos que o vocabulário adotado pelo DLG é abundante em referências ao conhecimento especializado do campo da linguística e da gramática, reforçando a projeção de público definida no prefácio: um estudioso desses campos específicos.

Diferenciando a designação de gênero que se faz entre objetos animados e inanimados, a definição do DLG reconhece a possibilidade de uma não correspondência entre o gênero da palavra e o seu referente no mundo?

a distinção dos sexos é um significado da categoria para os nomes de seres do reino animal, mas mesmo aí há nomes que só têm um gênero, independentemente do sexo (ex.: cônjuge, masculino; testemunha, feminino; jacaré, masculino; cobra, feminino), podendo o sexo ser indicado subsidiariamente pelos termos macho e fêmea apostos ao nome e sem concordância de gênero com ele, no caso de animais irracionais - um jacaré fêmea, uma cobra macho (nomes EPICENOS).

\footnotetext{
${ }^{9}$ A discussão sobre a sinalização gramatical como forma de inclusão de gênero traz questões pertinentes a respeito dessa relação entre palavra e referente. Um aprofundamento sobre esse debate pode ser encontrado em nossa dissertação de mestrado (MEDEIROS, 2016).
} 
Chamamos atenção para o modo como os exemplos que se aplicam a humanos e que se aplicam a animais são apresentados sequencialmente, não direcionando a qualquer reflexão sobre identidade de gênero. Ao elencar exemplos do reino animal para a explicação do funcionamento da categoria gênero ("jacaré", "cobra", "lobo"), ela é posta como natural e evidente: o gênero está dado, não é uma construção, e a língua dispõe de mecanismos para expressá-lo (não para construí-lo ou questioná-lo).

Quanto à diferença sexual, ainda que não seja apresentada com essa nomenclatura, ela está assinalada nos "substantivos referentes a seres do reino animal":

encontram-se não raro vocábulos diferentes para o masculino e feminino, como formas supletivas (v.): a) formados de semantemas distintivos (ex.: homem-mulher; bode-cabra); b) diferenciados por um sufixo lexical, na base de um mesmo semantema, podendo ter ou não o feminino a desinência - a (conde - condessa, com o masculino sem sufixo lexical e o feminino com o sufixo -essa provido da desinência - $a$; imperador - imperatriz, com os sufixos lexicais -dor e -triz para o masculino e o feminino, respectivamente, e sem a desinência - $a$ no feminino).

Desse modo, a definição do dicionário reconhece a especificidade da diferença sexual para seres do reino animal, cujo gênero não pode ser categorizado do mesmo modo que o gênero de objetos. A diferença sexual, posta pela distinção entre masculino e feminino, figura como um fato da natureza e da língua, no qual a sociedade não é evocada como fator condicionante: mesmo para falar de títulos ligados ao campo da política, como "imperador/imperatriz", a definição apenas constata a possibilidade de ocupação desses cargos por homens ou mulheres ${ }^{10}$.

Dessa análise, concluímos que a categoria de gênero conforme apresentada no DLG trata estritamente do funcionamento do gênero das palavras; os referentes para os quais a diferença de gênero poderia importar são evocados apenas como exemplo da flexão no campo lexical. Essa restrição pode ser justificada pelo objetivo do dicionário: ser uma fonte de estudo específico sobre linguística e gramática, campos nos quais o conceito de gênero tem um modo particular de funcionamento, que não necessariamente corresponderá à sua circulação em demais campos do conhecimento (incluída aí a língua geral).

${ }^{10}$ Salientamos que o reconhecimento da relação entre sociedade e língua não se restringe a textos que se focam na abordagem de gênero como fator sociocultural. É o caso, por exemplo, da Moderna Gramática Portuguesa, de Bechara (2009), na qual a seção Gênero abriga uma subseção denominada "O gênero nas profissões femininas" onde se lê que: “- A presença, cada vez mais justamente acentuada, da mulher nas atividades profissionais que até bem pouco eram exclusivas ou quase exclusivas do homem tem exigido que as línguas - não só o português - adaptem o seu sistema gramatical a estas novas realidades. Já correm vitoriosos faz muito tempo femininos como mestra, professora, médica, advogada, engenheira, psicóloga, filóloga, juíza, entre tantos outros. As convenções sociais e hierárquicas criaram usos particulares que nem sempre são unanimemente adotados na língua comum. Todavia, já se aceita a distinção, por exemplo, entre a Cônsul (= senhora que dirige um consulado) e a Consulesa (= esposa do Cônsul), a Embaixadora (= senhora que dirige uma Embaixada) e Embaixatriz (= esposa do Embaixador). Já para senador vigoram indiferentemente as formas de feminino senadora e senatriz para a mulher que exerce o cargo político ou para a esposa do senador, regra que também poucos gramáticos e lexicógrafos estendem a consulesa e embaixatriz." (BECHARA, 2009, p. 134) 
Passamos agora à análise do verbete gênero no Dicionário de Ciências Humanas (doravante DCH). Do mesmo modo como procedemos com o DLG, trazemos apenas os fragmentos que serão analisados (as supressões estão marcadas por [...]). O verbete é intercalado por um texto à parte, intitulado Masculino/Feminino: uma questão de natureza ou de cultura? As teorias das diferenças do sexo, delimitado em formato de box, cuja análise procederemos após a análise do texto do verbete.

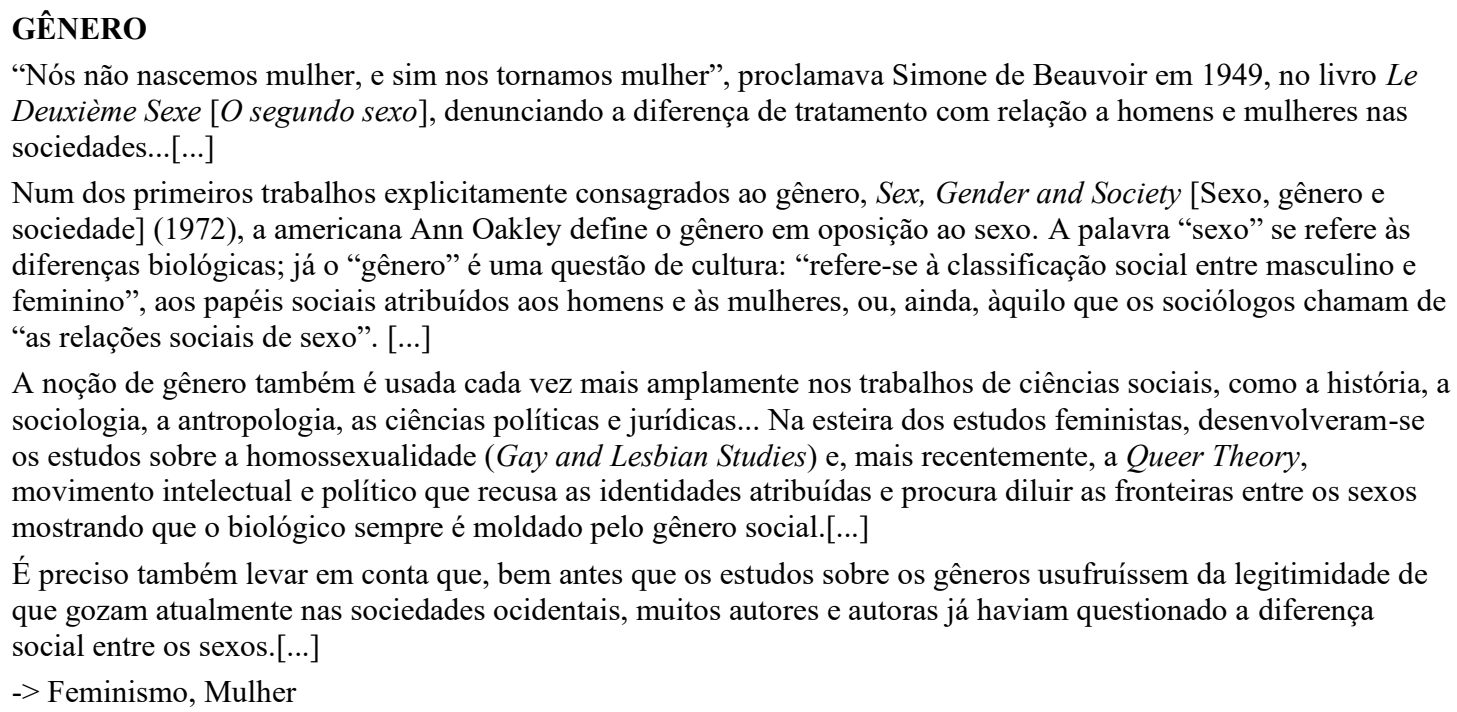

"Nós não nascemos mulher, e sim nos tornamos mulher", proclamava Simone de Beauvoir em 1949, no livro Le Deuxième Sexe [O segundo sexo], denunciando a diferença de tratamento com relação a homens e mulheres nas sociedades...[...]

Num dos primeiros trabalhos explicitamente consagrados ao gênero, Sex, Gender and Society [Sexo, gênero e sociedade] (1972), a americana Ann Oakley define o gênero em oposição ao sexo. A palavra "sexo" se refere às diferenças biológicas; já o "gênero" é uma questão de cultura: "refere-se à classificação social entre masculino e feminino", aos papéis sociais atribuídos aos homens e às mulheres, ou, ainda, àquilo que os sociólogos chamam de "as relações sociais de sexo". [...]

A noção de gênero também é usada cada vez mais amplamente nos trabalhos de ciências sociais, como a história, a sociologia, a antropologia, as ciências políticas e jurídicas... Na esteira dos estudos feministas, desenvolveram-se os estudos sobre a homossexualidade (Gay and Lesbian Studies) e, mais recentemente, a Queer Theory, movimento intelectual e político que recusa as identidades atribuídas e procura diluir as fronteiras entre os sexos mostrando que o biológico sempre é moldado pelo gênero social.[...]

É preciso também levar em conta que, bem antes que os estudos sobre os gêneros usufruíssem da legitimidade de que gozam atualmente nas sociedades ocidentais, muitos autores e autoras já haviam questionado a diferença social entre os sexos.[...]

$\rightarrow$ Feminismo, Mulher

\section{Quadro 5 - Gênero no Dicionário de Ciências Humanas}

Fonte: Elaborado pela autora com base em Dortier (2010).

O primeiro aspecto que destacamos é o formato enciclopédico: o enunciado definitório começa por uma citação, e não pelo formato de definição padronizada que encontramos nos demais dicionários. Assim como no DLG, o verbete do DCH apresenta uma breve retomada histórica do conceito analisado. Como diferença, é possível perceber que no DCH os desdobramentos não servem apenas para contextualizar diacronicamente, mas também para apresentar diferentes pontos de vista que se elaboram sobre o mesmo conceito.

Das possíveis acepções apresentadas no verbete, destacamos a atribuída à americana Ann Oakley, que, além de servir para estabelecer um marco temporal dos estudos de gênero, "define o gênero em oposição ao sexo": embora o restante de sua definição se assemelhe às definições encontradas nos dicionários de língua, relacionando gênero à cultura e à sociedade, a noção de oposição diferencia essa acepção das demais analisadas. Enquanto nas acepções dos dicionários de língua comum o gênero é posto em relação de continuidade com "a diferença sexual", o DCH, ao apresentar a noção de oposição, rompe com essa continuidade, postulando uma diferença marcante que se contrapõe a uma correspondência direta (como poderia ser interpretada pelas definições dos dicionários de língua). 
Essa diferente perspectiva é reafirmada pela explicação sobre a Queer Theory, "que recusa as identidades atribuídas e procura diluir as fronteiras entre os sexos mostrando que o biológico sempre é moldado pelo gênero social". A apresentação dessa teoria dentro do verbete gênero aponta uma ruptura com o postulado pelos dicionários de língua: enquanto estes afirmam que os gêneros são culturalmente atribuídos segundo a diferença sexual, a teoria aqui apresentada propõe um movimento contrário, no qual é o gênero social que molda o biológico. Abordando também a diluição de fronteiras, tal perspectiva de gênero permitiria refutar a existência de uma diferença a priori, considerando que esta apenas se molda às diferenciações estabelecidas pelo gênero social.

Finalmente, o texto do verbete conclui que os estudos de gênero são um campo de conhecimento antigo, dado que "bem antes que os estudos sobre os gêneros usufruíssem da legitimidade de que gozam atualmente nas sociedades ocidentais, muitos autores e autoras já haviam questionado a diferença social entre os sexos". Dessa conclusão, é possível afirmar que o verbete apresenta diferentes perspectivas para gênero de acordo com o campo dos estudos de gênero e seus desdobramentos contemporâneos, reconhecendo, no entanto, que, embora a legitimidade e a nomenclatura desse campo sejam recentes, o assunto de que ele se ocupa já era estudado muito anteriormente. Quanto a essa afirmação, não é estabelecido um marco temporal, mas a citação a Beauvoir nos dá pistas de que essa problemática seja investigada pelo menos desde a década de 1940. É pertinente destacar que tanto a obra citada quanto o seu trecho selecionado não utilizam a palavra gênero, mas sim sexo e homens e mulheres, o que confirma a constatação final do verbete quanto ao estudo já antigo da diferença social entre os sexos.

Passamos agora à análise do texto que acompanha, em formato de box, o verbete. Apresentando "as teorias das diferenças do sexo", o texto aborda duas principais perspectivas sobre o gênero: a natureza e a cultura. Essa divisão é interessante porque coloca separadamente aspectos que até então tinham sido apresentados como constitutivos do gênero de modo conjunto (com variações nas relações de sequencialidade, por exemplo), e não separados por ou. Nesse texto, os argumentos a favor da natureza ou da cultura são atribuídos a diferentes campos do conhecimento. A favor da natureza, figura a psicologia evolucionista/evolutiva (ambas denominações presentes no texto). A favor da cultura, figuram a etnologia, a psicologia do desenvolvimento, a psicologia social, a sociologia, a antropologia, a economia, a história e o direito. Destacamos que, embora o dicionário procure abranger diversas disciplinas das ciências humanas, a quantidade de áreas que são referidas a favor de uma mesma perspectiva é desproporcional em comparação à quantidade referida a favor da outra: essa disparidade pode se justificar seja por se tratar de perspectivas com diferentes graus de aceitabilidade por parte dos estudiosos que se dedicam ao estudo do gênero, seja para marcar a posição ocupada pelo lexicógrafo de preferência por uma em detrimento da outra. A leitura do DCH não permite afirmar de qual alternativa se trata, mas essa variação pode ser significativa para os sentidos de gênero na língua comum, como discutiremos na próxima seção.

Sobre a perspectiva que se baseia na biologia, a psicologia evolucionista, o texto afirma que ela "continua a fazer, principalmente na Europa, o papel de patinho feio no panorama das ciências humanas" e que "propõe teorias consideradas pouco politicamente 
corretas, segundo as quais as diferenças entre os dois sexos se explicariam por determinismos biológicos". Essa perspectiva é a única, dentre as diversas aqui analisadas, que não coloca a diferença sexual em relação com a cultura. $O$ gênero figura aqui como uma condição biológica que não é passível de interpretações ou modulações sociais. A diferença sexual, nessa perspectiva, é sinônima de gênero, numa relação direta e transparente.

Quanto às perspectivas que se baseiam na cultura, estas são apontadas como as originadoras dos estudos de gênero. É estabelecido um marco temporal por "há cerca de vinte anos" para a expansão desses estudos. No entanto, tal como aconteceu no verbete com a referência a Simone de Beauvoir, neste texto complementar também é referido pelo menos uma produção que é bastante anterior ao marco dos estudos de gênero: "A etnóloga Margaret Mead foi uma das primeiras a enfatizar, nos anos 1930, o caráter cultural e construído das identidades de sexo." Tal como na referência a Beauvoir, a nomenclatura utilizada para debater as diferenças não se vale de gênero, embora a reflexão que hoje se organiza em torno desse conceito já estivesse presente. Isso confirma a já citada diferença, sempre pertinente, entre conceito e palavra: embora a circulação da palavra ocupando o papel de um determinado campo de estudo seja recente, as questões que a atravessam já foram postas em outros termos. Na sequência do texto, são elencados exemplos sobre estereótipos, expectativas, violência simbólica e desigualdades. O texto conclui citando filósofas francesas cujas produções dão continuidade às reflexões de Beauvoir quanto ao "debate sobre o lugar das mulheres nas sociedades contemporâneas".

Dessa análise, é possível concluir que o DCH se vale de diferentes recursos para produzir um efeito de completude quanto às diferentes perspectivas de gênero que circulam nos campos das Ciências Humanas: o texto do verbete, que apresenta as perspectivas de modo mais enfático e direto, é intercalado por um texto que se marca como questionador desde o título. Além disso, podemos relacionar a referência constante a Simone de Beauvoir ao funcionamento das condições de produção, visto que se trata de um dicionário produzido na França, fazendo referência a autoras francesas, e de um verbete que foi traduzido para o Brasil sem adaptações (ao contrário de outros que constam no DCH, conforme indicado em sua folha de rosto).

Uma vez concluída a análise do verbete gênero nos quatro dicionários, passamos agora à discussão de algumas considerações suscitadas pela análise.

\section{ENTRE A ANTROPOLOGIA E A GRAMÁTICA, A MARCA DAS DIFERENÇAS}

Em todos os dicionários aqui analisados, foi possível identificar uma regularidade quanto à presença da diferença e da categorização nas definições. Assim, o gênero seria aquilo que categoriza a partir da diferença, e isso serve tanto para o gênero gramatical, que marca a diferença entre um jacaré e uma cobra, quanto para a identidade sexual, que marca socialmente diferenças entre homens e mulheres.

Algumas relações podem ser estabelecidas entre os verbetes apresentados nos diferentes tipos de dicionários que analisamos. A primeira para a qual chamamos atenção é a que diz respeito à definição de gênero nos dicionários de língua. É possível traçar um 
paralelo entre as reflexões propostas pelo campo dos estudos de gênero, os sentidos para gênero apresentados no DCH e seus sentidos nos dicionários de língua comum (quando estes incluem essa acepção): o gênero é uma construção cultural da diferença entre homens e mulheres. É interessante notar que, embora o DCH reconheça outras perspectivas de gênero, como aquela da psicologia evolutiva, o sentido que circula nos dicionários de língua é o da antropologia, havendo inclusive a rubrica que o identifica como tal. A abundância de diferentes campos do conhecimento que defendem a perspectiva da cultura como determinante para o gênero, como demonstramos na análise do $\mathrm{DCH}$, pode ser uma explicação para o fato de ser esta a acepção que figura nos dicionários de língua comum: embora haja perspectivas diferentes, o consenso entre diferentes áreas é responsável por legitimar um sentido que circule como predominante para além de seus campos específicos.

A segunda relação que destacamos é aquela que se estabelece entre o conhecimento especializado e o conhecimento geral, segmentação que se materializa na diferenciação entre dicionários de língua e dicionários especializados, sem que isso estabeleça fronteiras intransponíveis. É o que acontece, por exemplo, na acepção de gênero que diz respeito ao conhecimento metalinguístico. Ainda que a definição apresentada no DLG seja muito mais aprofundada, como é o esperado de um dicionário especializado, uma definição mais simples sobre gênero gramatical estava presente em todos os dicionários de língua consultados (inclusive aqueles que foram descartados do corpus). Retomando Collinot e Mazière (1997), lembramos que o dicionário é construído para um público suposto, projetado, com certo conhecimento sobre a língua e certo objetivo em sua consulta. De nossa análise, podemos concluir que ao público projetado para os dicionários de língua é reservado um certo conhecimento especializado, aquele que deve ser ensinado na escola e diz respeito ao conhecimento metalinguístico, mas não necessariamente aquele que circula nas ciências humanas e na antropologia. A informação de que o gênero dos substantivos e adjetivos flexiona entre masculino e feminino é mais facilmente encontrada do que aquela que diz respeito aos papéis e status que homens e mulheres ocupam na sociedade.

E isso conduz à terceira relação que queremos destacar: ainda segundo Collinot e Mazière (1997), o dicionário representa um engajamento militante, que tem a ver com a ideia que se tem de língua, e representa também um engajamento social. Desse modo, é interessante voltar o olhar mais uma vez para quais sentidos foram apresentados para gênero nos dicionários analisados e mesmo nos dicionários excluídos. Que língua e que sociedade são delineadas por um dicionário direcionado ao público escolar, por exemplo, que silencia a identidade sexual e seus desdobramentos antropológicos nas suas acepções de gênero? Por que esse sentido em específico tem uma ocorrência menor que aquele gramatical, que demonstra uma instrumentalização da língua e, mais do que isso, direciona-se a um público escolarizado, para o qual interessa a flexão de adjetivos e substantivos? Sendo o dicionário um discurso atravessado por ecos de outros discursos, nossa análise aponta para uma heterogeneidade discursiva na qual o conhecimento desenvolvido pela escolarização formal parece ser indispensável, enquanto aquele que diz respeito a um modo significativo de organizar a sociedade (e que vem sendo evocado em diversas culturas por diversas outras nomenclaturas além de gênero), não restrito ao ambiente dos bancos escolares, só encontra momentos excepcionais nos quais pode emergir. 
Partindo de nosso objetivo inicial de investigar os modos como a diferença sexual e a identidade de gênero podem ser elaboradas ou silenciadas em diferentes instrumentos linguísticos, traçamos um percurso que nos permitiu refletir como a opacidade de gênero era textualizada em seus diferentes sentidos por diferentes instrumentos linguísticos. Dos dicionários de língua aos dicionários especializados, procuramos tanto por regularidades que atravessassem suas diferentes definições quanto especificidades que caracterizassem seu uso em diferentes campos do conhecimento.

De nossa análise, foi possível concluir que gênero está sempre relacionado a diferenças e categorias, e o que varia entre diferentes acepções são as relações estabelecidas com essas diferenças. É desse modo que gênero tem sua diferença significada pela língua comum, pela antropologia, pela gramática, pela cultura, fazendo circular sentidos que delineiam seu funcionamento neste ou naquele campo e mesmo que extrapolam determinados campos, legitimando sentidos cabíveis de circular na língua comum. Nos casos em que apenas algumas acepções foram incluídas no verbete, foi possível relacionar o silenciamento aos diferentes campos de saber, bem como às condições de produção específicas de cada edição, permitindo identificar uma divisão das acepções entre aquelas que são unanimemente compartilhadas entre o público não especializado e aquelas que nem sempre circularão entre todos os públicos.

Nesse sentido, deixamos como reflexão final a constante disputa pelos sentidos que é constitutiva da atividade linguageira, da qual os instrumentos linguísticos são o registro material. As perguntas sobre gênero que apresentamos no início do artigo serão respondidas diferentemente a depender dos conhecimentos que sejam priorizados no instrumento linguístico que se consulte, e foram os efeitos dessas diferenças que procuramos demonstrar.

\section{AGRADECIMENTOS}

Este artigo é resultado parcial do exame de qualificação de área realizado como prérequisito do doutorado em Linguística. Agradeço à Profa. Dra. Carolina Maria Rodríguez Zucolillo pela orientação durante a escrita, e à Profa. Dra. Ana Cláudia Fernandes Ferreira e ao Prof. Dr. José Horta Nunes pela avaliação e pelos comentários.

\section{REFERÊNCIAS}

BECHARA, E. Moderna gramática portuguesa. 37. ed. rev., ampl. e atual. conforme o novo Acordo Ortográfico. Rio de Janeiro: Nova Fronteira, 2009.

COLLINOT, A.; MAZIÈRE, F. Un prêt à parler: le dictionnaire. Paris: Presses Universitaires de France, 1997.

MAZIÈRE, F. O enunciado definidor: discurso e sintaxe. In: GUIMARÃES, Eduardo. (Org.) História e sentido na linguagem. Campinas: Pontes, 1989. p. 47-60. 
MEDEIROS, L. V. A. Essa língua não me representa: discursos sobre língua e gênero. 105f. Dissertação (Mestrado em Letras) - Instituto de Letras, Universidade Federal do Rio Grande do Sul. Porto Alegre, RS: 2016.

NUNES, J. H. Discurso e instrumentos linguísticos no Brasil: dos relatos de viajantes aos primeiros dicionários. 269f. Tese (Doutorado em Linguística) - Instituto de Estudos da Linguagem, Universidade Estadual de Campinas. Campinas, SP: 1996.

OLIVEIRA, S. E. de. Cidadania: história e política de uma palavra. Campinas: Pontes Editores, RG Editores, 2006.

ORLANDI, E. As formas do silêncio: no movimento dos sentidos. 6. ed. Campinas: Ed. Unicamp, 2007.

ORLANDI, E; GUIMARÃES, E. Formação de um espaço de produção linguística: a gramática no Brasil. In: ORLANDI, E. (Org). História das ideias linguísticas: construção do saber metalinguístico e constituição da língua nacional. Campinas/Cáceres: Pontes/Unemat, 2001.

SILVERIS, D. Política de constituição do dicionário Caldas Aulete Digital. 199 f. Tese (Doutorado em Letras) - Instituto de Letras, Universidade Federal do Rio Grande do Sul: Porto Alegre, RS. 2018.

WILLIAMS, R. Palavras-Chave: um vocabulário de cultura e sociedade. Tradução de Sandra Guardini Vasconcelos. São Paulo: Boitempo, 2007.

DICIONÁRIOS

ACADEMIA BRASILEIRA DE LETRAS. Dicionário Escolar da Língua Portuguesa. 2. ed. São Paulo: Companhia Editora Nacional, 2008.

AULETE, Caldas. Aulete Digital - o dicionário da língua portuguesa na internet. Dicionário Caldas Aulete, versão online. Disponível em: http://www.aulete.com.br/. Acesso em: 10 ago. 2018.

CAMARA JUNIOR, Joaquim Mattoso. (1956) Dicionário de linguística e gramática: referente à língua portuguesa. 28. ed. Petrópolis, RJ: Vozes, 2011.

DORTIER, Jean-François (Dir.). Dicionário de ciências humanas. Revisão e coordenação da tradução Márcia Valéria Martinez de Aguiar. São Paulo: Editora WMF Martins Fontes, 2010.

FERREIRA, Aurélio Buarque de Holanda. (1999) Novo Aurélio Século XXI: o dicionário da língua portuguesa. 5. ed. Rio de Janeiro: Nova Fronteira, 2010.

HOUAISS, Antônio; VILLAR, Mauro de Salles. (2001) Dicionário Houaiss da Língua Portuguesa. Rio de Janeiro: Objetiva, 2009.

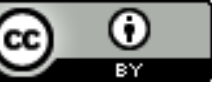

Este texto está licenciado com uma Licença Creative Commons Atribuição 4.0 Internacional. 